\title{
TIRAI OTOMATIS BERBASISKAN ARDUINO UNTUK MENINGKATKAN KONSENTRASI BELAJAR DAN MINAT SISWA TERHADAP TEKNOLOGI PADA SDN O03 BINAAN TANJUNGPINANG BARAT
}

\author{
Deny Nusyirwan ${ }^{1}$, Nadhifah Hasi Daiichi ${ }^{2}$, Prasetya Perwira Putra Perdana ${ }^{3}$ \\ ${ }^{1,2,3}$ Program Studi Teknik Elektro, Fakultas Teknik, Universitas Maritim Raja Ali Haji (UMRAH) \\ Jl. Politeknik Senggarang, Tanjungpinang 29100 \\ Email: denynusyirwan@umrah.ac.id
}

\begin{abstract}
Curtains are a means to regulate air circulation in our homes, control the sunlight that enters the room, maintain privacy in the room, and also as a complement to the interior of the house. As for in school, curtains have the main function as a window cover to avoid excessive lighting so that it can cause hot air so that it disrupts the smooth learning process of students. Therefore, one of the proposed technological innovations is Automatic Curtain based on the LDR sensor (Light Dependent Resistor). Automatic curtain based on LDR sensor (Light Dependent Resistor) is a system design where the LDR sensor when getting light will then pass information to the Arduino microcontroller, then Arduino will give an order to the servo to work closing the curtain. Automatic Curtain based on LDR sensor consists of several main devices, namely Arduino Uno, Micro Servo, Resistor, LED Lights, and several Male to Male Jumper Cables. The research process applies an engineering design process with a double diamond model approach introduced by the British Design Council, which explains the need for user-based design thinking to get an innovation that is the right solution at school. The process begins with social ethnographic research, direct observation in schools to gather information, followed by an outpouring of ideas on problems that exist in schools, determining the main problems in schools, the process of outlining the ideas of solutions given to the main problems and discussions to determine the main solutions. In the next stage is the making of simple prototypes and usability testing to get an evaluation of the solutions given
\end{abstract}

Keywords: Curtain, sunlight, arduino, student

\begin{abstract}
Abstrak. Tirai merupakan sarana untuk mengatur sirkulasi udara di rumah kita, pengontrol cahaya matahari yang masuk ke dalam ruangan, menjaga privasi yang berada di dalam ruangan, dan juga sebagai pelengkap interior rumah. Adapun di sekolah, tirai memiliki fungsi utama sebagai penutup jendela untuk menghindari pencahayaan yang berlebihan sehingga dapat menimbulkan udara panas sehingga mengganggu kelancaran proses belajar siswa. Oleh karena itu, salah satu inovasi teknologi yang diusulkan adalah Tirai Otomatis berbasis sensor LDR (Light Dependent Resistor). Tirai Otomatis berbasis sensor adalah suatu perancangan sistem dimana sensor LDR apabila mendapat cahaya maka akan meneruskan informasi ke mikrokontroler Arduino, selanjuntya Arduino akan memberikan perintah kepada servo untuk bekerja menutup tirai. Tirai Otomatis berbasis sensor LDR terdiri dari beberapa perangkat utama yaitu Arduino Uno, Micro Servo, Resistor, Lampu LED, dan beberapa Kabel Jumper Male to Male. Proses penelitian menerapkan sebuah proses desain rekayasa dengan pendekatan model double diamond yang telah diperkenalkan oleh British Design Council, dimana menjelaskan akan perlunya design thinking berbasis kepada pengguna untuk mendapatkan sebuah inovasi yang merupakan solusi yang tepat di sekolah. Proses dimulai dengan penelitian secara sosial etnografi, observasi secara langsung di sekolah untuk mengumpulkan informasi, dilanjutkan curahan gagasan terhadap permasalahan yang ada di sekolah, menentukan permasalahan utama di sekolah, proses curahan gagasan solusi yang di berikan terhadap permasalahan utama dan diskusi untuk menentukan solusi utama. Pada tahapan selanjutnya adalah pembuatan purwarupa sederhana dan pengujian kegunaan untuk mendapatkan evaluasi terhadap solusi yang diberikan.
\end{abstract}

Kata kunci : Tirai, cahaya, arduino, siswa

\section{PENDAHULUAN}

Lingkungan sekolah merupakan lingkungan dimana para siswa melakukan kegiatan. Banyak kegiatan yang bisa dilakukan para siswa di sekolah, mulai dari aktivitas belajar, bermain, berolahraga, serta kegiatan lainnya. Oleh karena itu, lingkungan di sekitar siswa harus memungkin untuk melakukan aktivitasaktivitas harian yang telah disesuaikan dengan aktivitas/kegiatan yang sedang mereka lakukan 
agar tidak mengganggu kegiatan yang sedang berlangsung. Dengan menyediakan fasilitas ruangan yang berfungsi untuk melindungi siswa dari panas terik matahari dan hujan Permasalahan yang ditemukan adalah ketika siswa/siswi melakukan kegiatan belajar dan terkena paparan panas sinar matahari secara langsung maka siswa akan merasa kepanasan, gusar dan mulai tidak fokus dalam kegiatan belajar mengajar. Penelitian dimulai dengan observasi secara langsung di sekolah dan wawancara.

Perguruan tinggi adalah merupakan pendorong untuk penerapan inovasi di masyarakat, seiring dengan perkembangan teknologi juga terjadi transformasi penggunaan peralatan dari yang konvensional ke arah yang komputerisasi (Budiman, Utomo, dan Rahayu, 2019). Oleh sebab itu, didalam penelitian ini akan untuk menghasilkan sebuah inovasi teknologi berupa otomatisasi pada tirai di ruangan kelas berbasiskan Arduino uno yang di integrasikan dengan sensor LDR untuk meningkatkan konsentrasi siswa ketika mengikuti pelajaran.

Dari hasil observasi maka dilanjutkan dengan tahapan brainstorming untuk mendapatkan beberapa usulan solusi dari beberapa permasalahan yang ditemukan. Tahapan sketching (menggambar di atas kertas) dan pembuatan purwarupa sederhana yang diperlukan untuk mendapatkan bentuk rancangan yang sesuai dan tidak kalah pentingnya adalah tahapan pengujian purwarupa serta pengalaman pengguna untuk mendapatkan masukan dari calon pengguna yang akan dipergunakan untuk memperbaiki rancangan sebelumnya.

\section{Penelitian terdahulu}

Pada sebuah tugas ahir dengan judul Prototipe tirai otomatis berbasis mikrokontroller ATmega 8, menghasilkan tirai yang dapat terbuka dan tertutup secara otomatis atau dengan pengontrolan melalui saklar tekan. Dari hasil pengujian, didapatkan keberhasilan $100 \%$. Adapun perangkat yang dipergunakan adalah mikrokontroler, sensor LDR, saklar tekan dan motor servo (Wulandari. 2017).

Sedangkan pada penelitian yang berjudul Otomatisasi lampu, tirai, dan kipas angin menggunakan mikrokontroler untuk menghemat energi listrik, telah melalukukan perbandingan jumlah energi yang dapat dihemat dengan menggunakan sistem otomatis. Penelitian ini dilatorbelakangi dengan permasalahan keterbatasan energi yang dihasilkan dari pembangkit yang mempergunakan bahan bakar fossil. Dari hasil pengujian didapatkan hasil bahwa penghematan dapat mencapai $50 \%$. Sedangkan sistem kontrol yang dipergunakan adalah mikokontroler ATMega 8535 ( Lidiawati, Pranoto, Waslaluddin, dan Hidayat, 2017)

Adapun penelitian yang berjudul Rancang bangun kendali gordeng dengan saklar lampu otomatis berbasis Smartphone android, melihat akan perlunya sebuah pengaturan secara manual untuk buka tutup gordeng. Selain penerapan sistem otomatis, telah dirancang sistem kendali nirkabel menggunakan Bluetooth (Ihsanto, dan Rifky, 2015)

Pada penelitian yang berjudul Purwarupa sistem otomasi buka tutup tirai berbasis Light Dependent Resistor melihat perlunya sebuah inovasi untuk membuka dan menutup tirai tepat pada waktunya. Oleh sebab itu telah dirancang sebuah sistem buka dan tutup tirai yang otomatis dan sebagai alternatif juga dapat diatur sesuai waktu yang sudah ditentukan dengan mempergunakan komponen RTC (Real Time Clock) (Ahmad, dan Dharmawan, 2011).

\section{METODE PELAKSANAAN}

Peranan penting bagi ilmuwan pada abad ke21 adalah berperan serta dalam mendidik masyarakat tentang metode dan hasil proses ilmiah (Kastner, dan Knight, 2017), oleh sebab itu diperlukan proses desain rekayasa untuk mampu menghasilkan inovasi berbasiskan teknologi yang semakin berkembang dan memiliki fungsi yang tepat dan mudah untuk digunakan. Jika di masa lalu desainer dievaluasi hanya berdasarkan pada keterampilan teknis mereka, di masa depan akan lebih banyak lagi kebutuhan untuk desainer yang bersedia bekerja dengan pendekatan yang lebih sistemik dan strategis dalam skala yang lebih besar (Irbīte, dan Strode, 2016). Proses Desain Rekayasa adalah merupakan sebuah proses didalam mendesain dengan berpusat kepada pengguna. dimulai dengan etnografi hingga menghasilkan sebuah 
purwarupa yang merupakan sebuah konsep solusi yang sesuai dengan kebutuhan di masyarakat.

Proses ini memiliki 4 tahapan, pada tahapan awal dimulai dengan observasi secara luas di masyarakat untuk mendapatkan permasalahanpermasalahan, tahapan kedua adalah proses pengerucutan dengan melakukan pemilihan permasalahan utama, tahapan ketiga adalah mengembangkan ide-ide sebagai solusi terhadap permasalahan utama dan tahapan terahir adalah menetukan solusi utama untuk dapat dilanjutkan ke tahapan pembuatan purwarupa dan pengujian terhadap pengguna, sila lihat Gambar 1. Dalam tahapan pengujian terhadap pengguna akan terdapat proses iterasi untuk mendapatkan masukan untuk perbaikan inovasi nantinya.

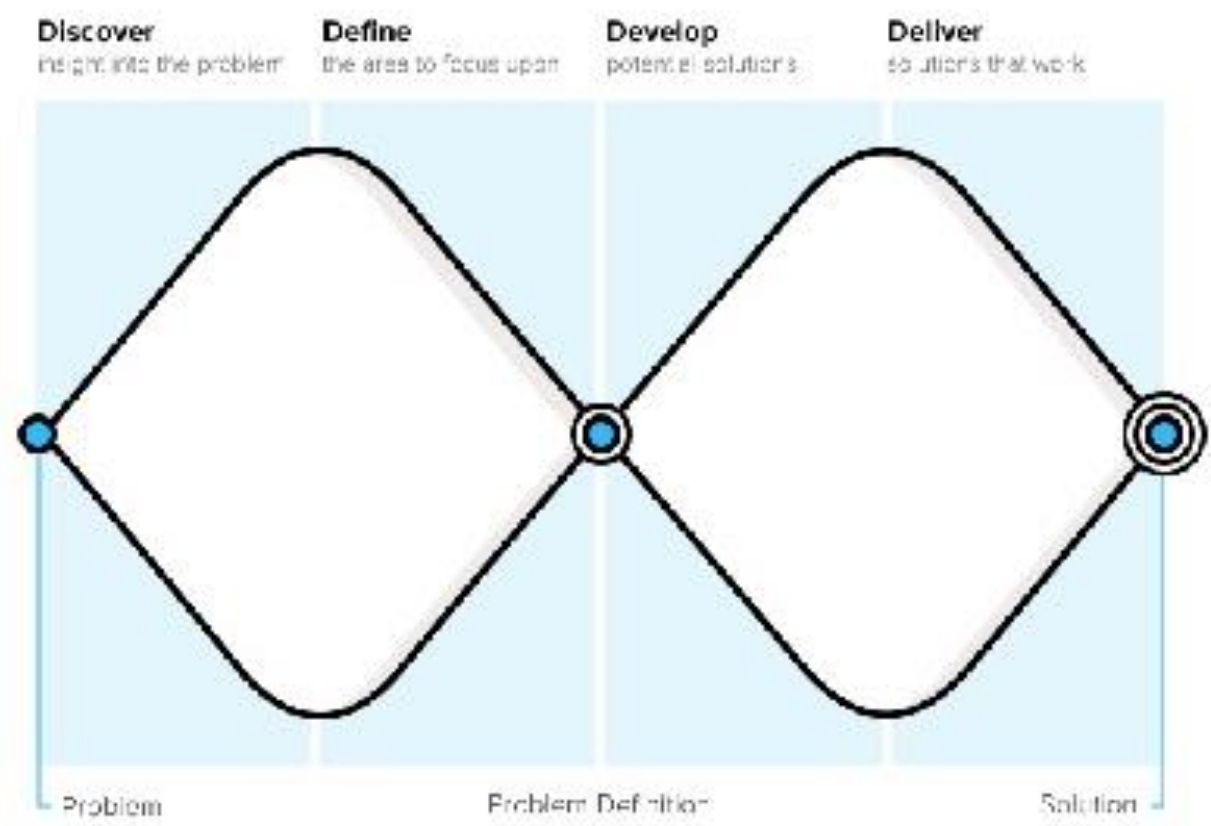

Gambar 1. Tahapan pada Proses Desain Rekayasa

Desain dan pemasaran adalah dua bagian penting dalam proses penelitian untuk melakukan pengembangan produk dan menghasilkan inovasi berbasis teknologi. Kedua bidang tersebut dapat saling melengkapi namun memiliki fokus yang berbeda. Peneliti untuk bidang desain sangat ingin tahu apa yang benar-benar dibutuhkan oleh calon pengguna dan bagaimana sebenarnya pengguna akan menggunakan produk yang sedang dipersiapkan. Sedangkan untuk peneliti di bidang pemasaran ingin tahu apa yang akan dibeli pengguna, termasuk mempelajari bagaimana pengguna membuat keputusan pembelian. Oleh sebab itu, dengan tujuan yang berbeda ini akan mengarahkan kedua kelompok tersebut untuk mengembangkan metode penyelidikan yang berbeda pula. Desainer cenderung menggunakan metode observasi kualitatif yang dengannya mereka dapat mempelajari orang secara mendalam, memahami bagaimana mereka melakukan kegiatan mereka dan faktor lingkungan yang ikut berperan. Metode ini sangat memakan waktu, sehingga didalam penelitian ini hanya memeriksa sejumlah kecil orang.. Adapun metode observasi yang dipergunakan adalah metode observasi peneliti sebagai peserta (observer as participant), yaitu kelompok yang sedang diteliti mengetahui tentang keberadaan peneliti, namun peneliti tidak ikut serta melakukan kegiatan dan aktifitas didalam kelompok yang sedang diteliti. Lokasi penelitian dilakukan di SDN 003 Binaan Tanjung pinang, Kepulauan Riau, lihat Gambar 2. 


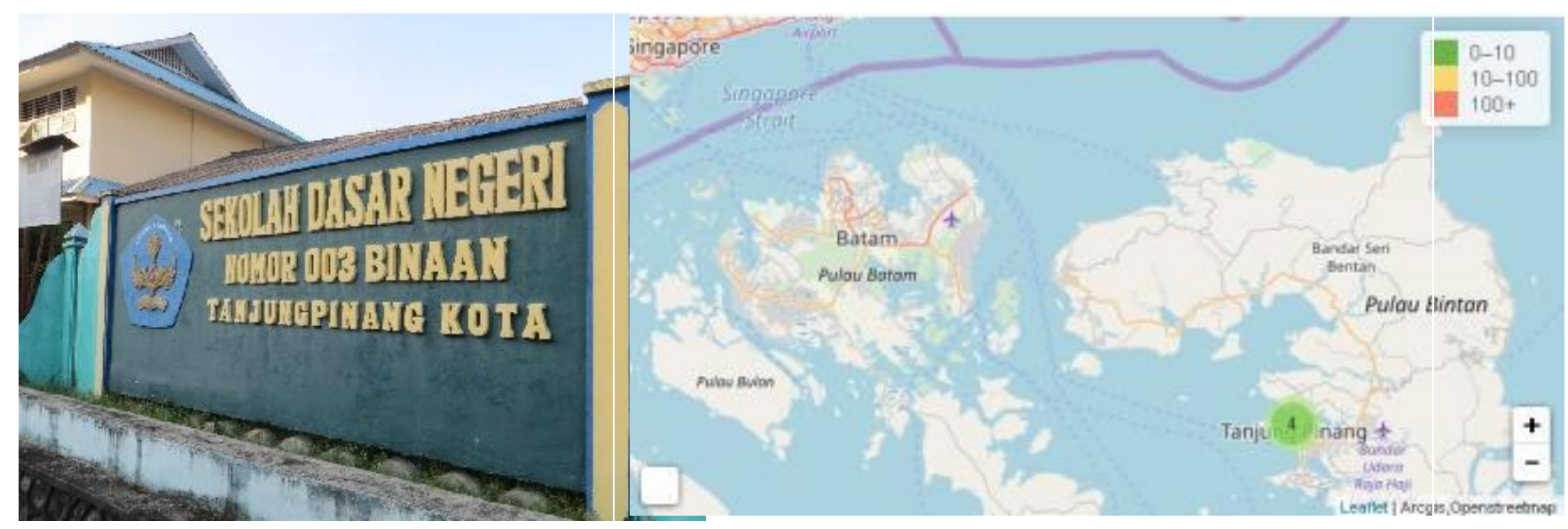

Gambar 2. Lokasi SDN 003 Binaan Tanjung pinang

\section{Proses Etnografi}

Langkah awal dari Proses Desain Rekayasa, yang merupakan aktivitas pegamatan atau observasi secara langsung ke masyarakat di suatu daerah untuk mendapatkan data yang akurat sehingga mampu menghasilkan sebuah solusi yang tepat. Pada Gambar 3 menampilkan keadaaan di SDN 003 Binaan Tanjung pinang untuk mendapatkan data-data yang di perlukan.

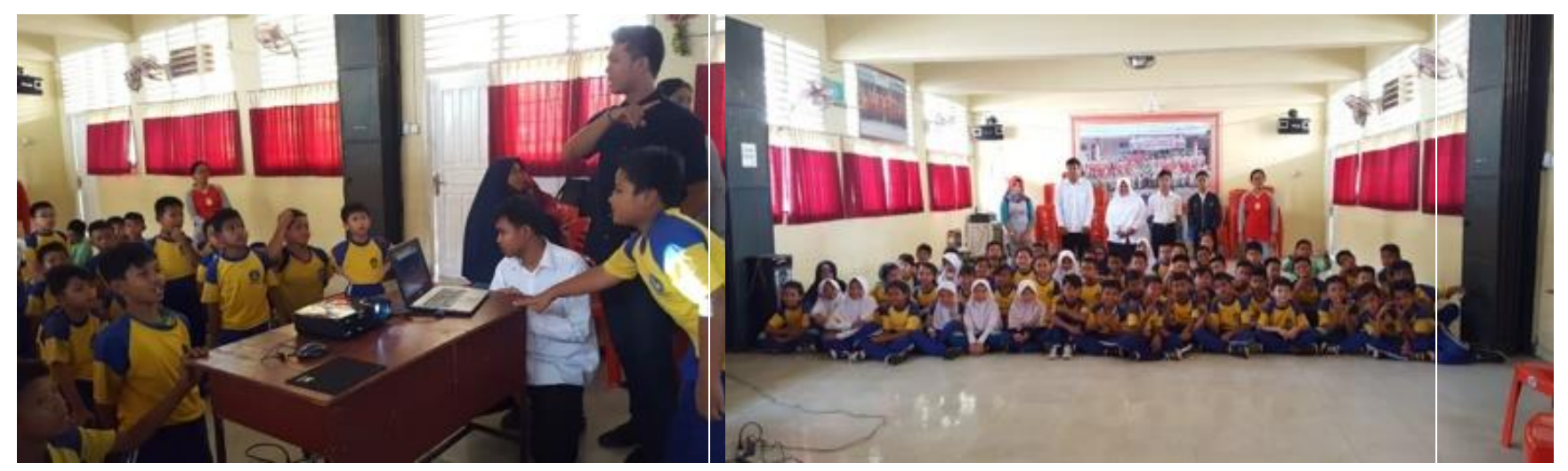

Gambar 3. Suasana di SDN 003 Binaan Tanjung pinang

Metode etnografi yang diterapkan pada penelitian ini adalah peneliti sebagai peserta, dimana kelompok yang sedang diteliti mengetahui tentang keberadaan peneliti, namun peneliti tidak ikut serta melakukan kegiatan dan aktifitas didalam kelompok yang sedang diteliti (Wagner, Kawulich, dan Garner, 2012). Pada Gambar 4 memperlihatkan peneliti melakukan proses pengumpulan informasi di SDN 003 Binaan Tanjung pinang.

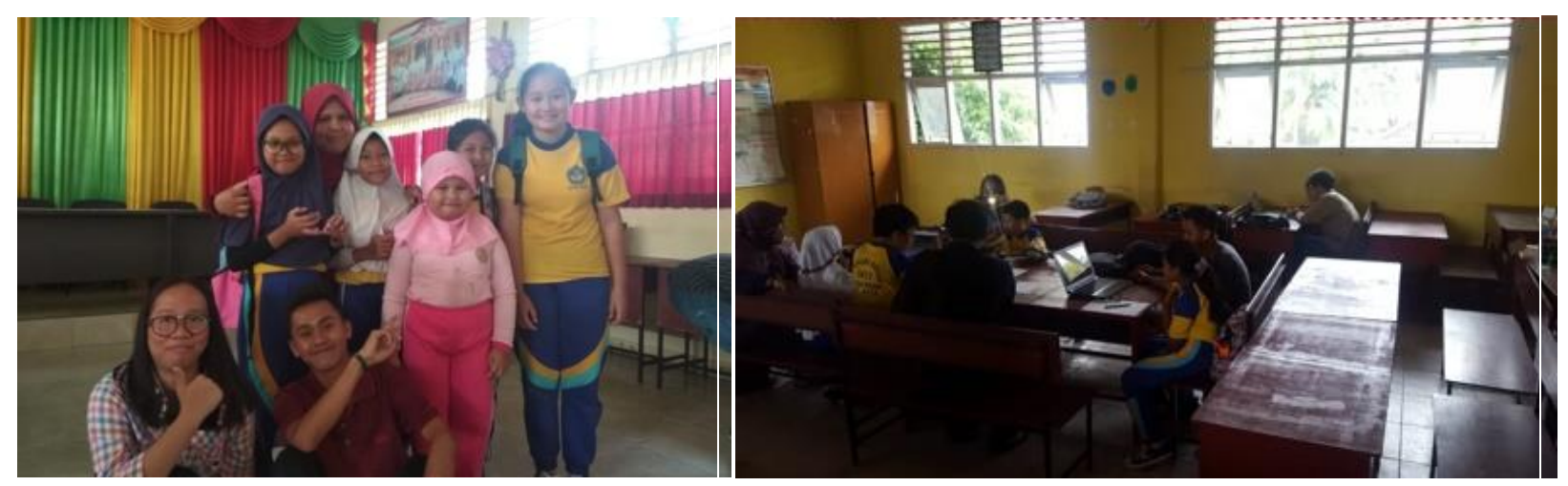

Gambar 4. Mengumpulkan informasi mengenai permasalahan di sekolah melalui siswa 


\section{KARYA UTAMA}

Sistem kerja Tirai Otomatis ini menggunakan mikrokontroler Arduino Uno ATmega 328, Tirai Otomatis ini menggunakan Micro Servo 99 untuk menutup Tirai Jendela saat sensor cahaya atau sensor LDR (Light Dependent Resistor) mengenai cahaya. Sistem Tirai Otomatis ini juga dilengkapi dengan 1 LED tanda (hijau,servo menyala dan tirai tertutup). Cahaya yang digunakan bisa dari Flash handphone atau sumber cahaya lainnya. Jika sensor LDR (Light Dependent Resistor) dikenai cahaya, maka dengan otomatis lampu LED hijau akan menyala dan motor servo akan bergerak untuk menutup tirai secara otomatis... Sila lihat

\section{Gambar 5.}

Adapun komponen yang diperlukan untuk pembuatan purwarupa dengan estimasi harga adalah sila lihat pada Tabel 1.

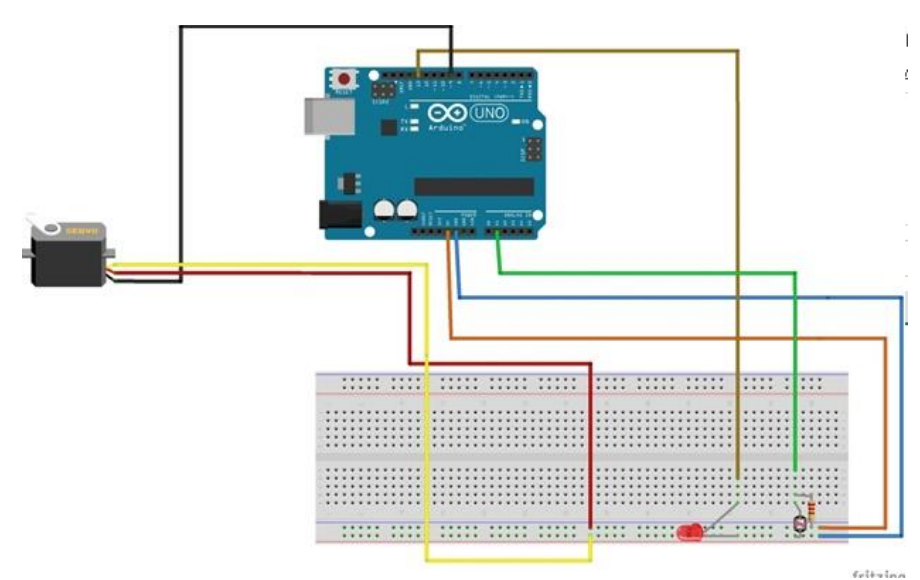

Gambar 5. Rangkaian elektronika sistem Tirai otomatis

Tabel 1. Estimasi anggaran (Bukalapak, diakses 28 Mei 2019)

\begin{tabular}{|c|l|c|c|c|}
\hline No. & Barang & Jumlah & Harga (Rp) & Total (Rp) \\
\hline 1 & Arduino & 1 & 80000 & 80000 \\
\hline 2 & Breadboard & 1 & 32000 & 32000 \\
\hline 3 & Kabel Jumper & 10 & 1000 & 10000 \\
\hline 4 & LED & 2 & 1000 & 2000 \\
\hline 5 & Res istor & 2 & 500 & 1000 \\
\hline 6 & Mikro Servo & 1 & 40000 & 25000 \\
\hline 7 & Sensor LDR & 1 & 2500 & 11000 \\
\hline & Jumlah & & & $\mathbf{1 6 1 0 0 0}$ \\
\hline
\end{tabular}

Uno R3 adalah merupakan sebuah mikrokontroller, dimana mikrokontroler tersebut akan memproses input yang diberikan melalui bahasa pemograman open source sehingga akan menghasilkan output. Cukup hubungkan Arduino dengan kabel USB ke PC atau Mac/Linux anda, jalankan software Arduino sudah bisa untuk memprogram chip ATmega328. Sila lihat Gambar 6.

Breadboard adalah dasar konstruksi sebuah sirkuit elektronik dan merupakan purwarupa dari suatu rangkaian elektronik. Breadboard banyak digunakan untuk merangkai komponen, karena dengan menggunakan breadboard, pembuatan purwarupa tidak memerlukan proses menyolder (langsung tancap ). Karena sifatnya yang solderless alias tidak memerlukan solder sehingga dapat digunakan kembali dan dengan demikian sangat cocok digunakan pada tahapan proses pembuatan purwarupa serta membantu dalam berkreasi dalam desain sirkuit elektronika., sila lihat Gambar 7. 


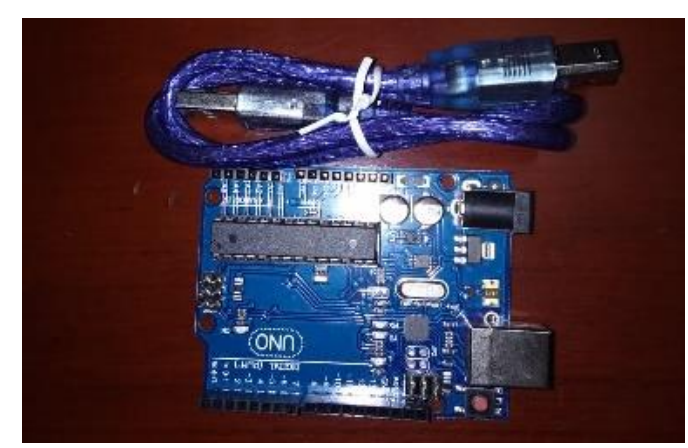

Gambar 6. Arduino Uno

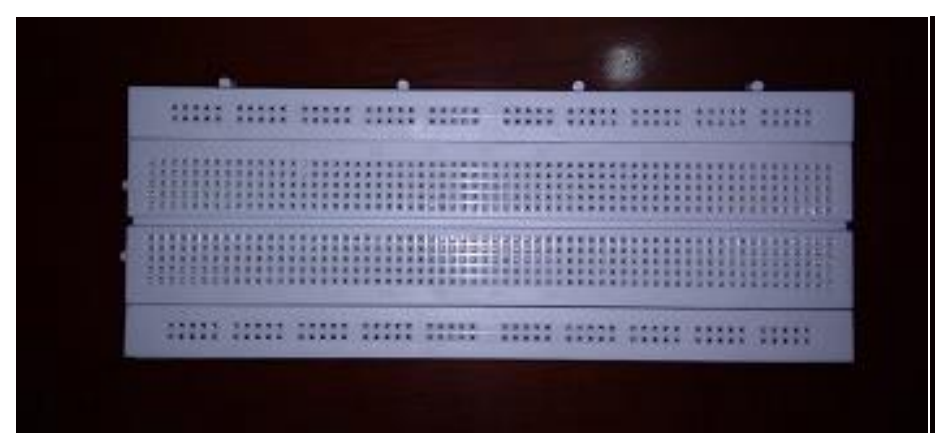

Gambar 7. BreadBoard

Kabel jumper adalah kabel yang di dipasangkan dengan mudah ke dalam berbagai pergunakan untuk menghubungkan satu perangkat elektronika. Berbeda dengan Lampu komponen dengan komponen lain ataupun Pijar, LED tidak memerlukan pembakaran menghubungkan jalur rangkaian yang terputus filamen sehingga tidak menimbulkan panas pada breadboard, sila lihat Gambar 8. LED dalam menghasilkan cahaya. Oleh karena itu, adalah sebuah komponen elektronika yang akan LED dengan bentuk yang kecil telah banyak menampilkan cahaya apabila diberikan tegangan. dipergunakan sebagai lampu penerang untuk Adapun bentuk LED mirip dengan sebuah mengganti lampu tabung. Sila lihat Gambar 9. bohlam (bola lampu) yang kecil dan dapat

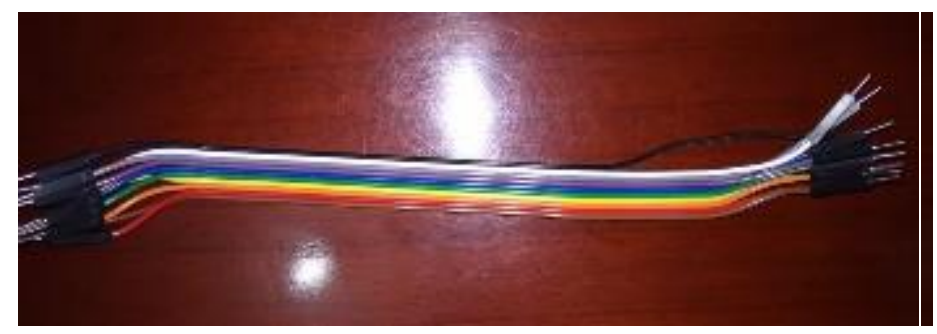

Gambar 8. Kabel Jumper

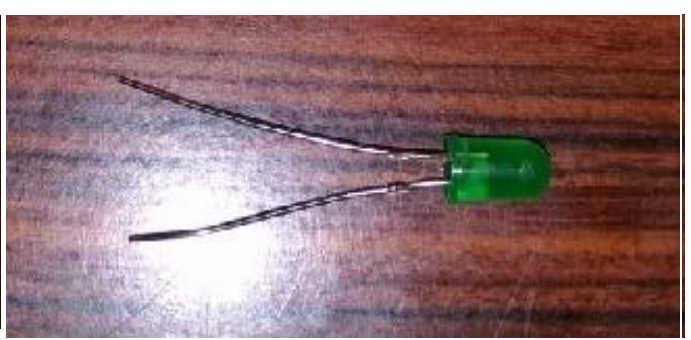

Gambar 9 . LED

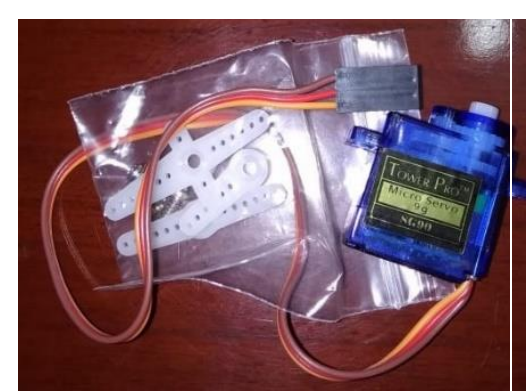

Gambar 10. Mikro Servo

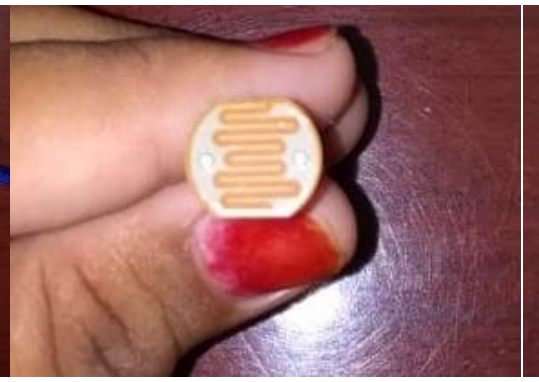

Gambar 11 . Sensor Cahaya LDR
Mikro servo adalah sebuah motor DC yang dilengkapi dengan rangkaian kendali. Motor servo disusun dari sebuah motor DC, roda gigi, potensiometer dan rangkaian kontrol. Potensiometer memiliki berfungsi untuk menentukan batas maksimum putaran sumbu motor. Sila lihat Gambar 10.
Sensor LDR adalah jenis resistor yang perubahan resistansi nya tergantung dari besar kecilnya cahaya yang diterima. Sila lihat Gambar 11. Resistor adalah komponen Elektronika Pasif yang memiliki nilai resistansi atau hambatan tertentu yang berfungsi untuk membatasi dan mengatur arus listrik dalam suatu rangkaian Elektronika. 
fungsi-fungsi Resistor di dalam rangkaian elektronika memiliki fungsi pembatas dan pengatur arus listrik, serta pembagi dan penurun tegangan listrik. Sila lihat Gambar 12.

\section{ULASAN KARYA}

Tahapan selanjutnya adalah curahan gagasan permasalahan yang ditemukan di sekolah dari hasil observasi, dimana semua permasalahan yang ditemukan akan di dokumentasikan. Proses ini adalah merupakan tahapan yang penting, karena sangat diharapkan bahwa solusi yang akan dihasilkan adalah merupakan solusi yang dibutuhkan, bukan solusi yang diminta oleh calon

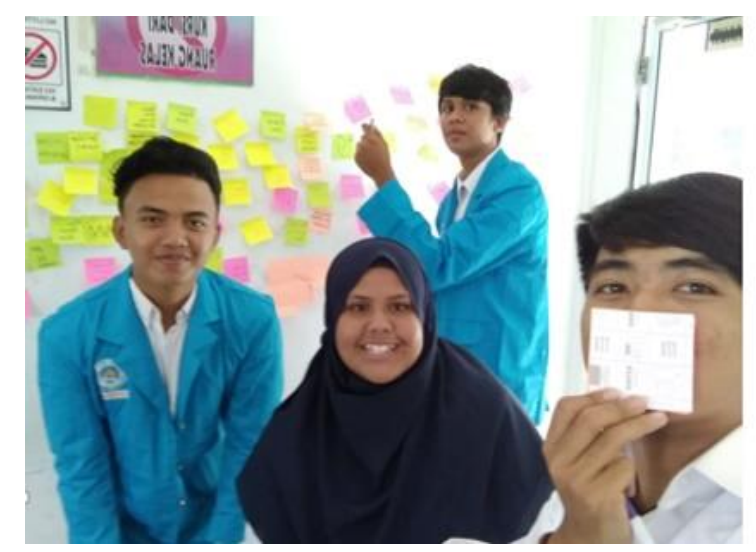

Gambar 13. Proses pengumpulan masalah

Permasalahan utama adalah satu permasalahan yang akan dijadikan landasan untuk langkah penentuan solusi, dalam tahapan ini akan dilakukan proses pengerucutan masalah, dimulai dengan pengelompokan masalah dan selanjutnya di pilih satu masalah saja, lihat Gambar 14. Proses diskusi bersama sesama anggota kelompok dengan saling memberikan penjelasan terhadap masalah yang akan dijadikan masalah utama diperlukan untuk mendapatkan informasi-informasi yang belum dapat disampaikan pada tahapan sebelumnya. Adapun permasalahan utama dari penelitian ini adalah cahaya matahari yang masuk ke ruangan kelas. pengguna. Pola penyampaian gagasan secara bebas akan sangat diperlukan untuk memotivasi peneliti untuk mampu berpikir inovatif dan kreatif. Curahan gagasan yang bersifat luas adalah merupakan pondasi bagi rekayasawan untuk mampu menghasilkan sebuah inovasi yang berbasiskan teknologi. Hal ini sering dipahami dengan $\mathrm{T}$ concept, dimaksudkan bahwa inovasi yang dihasilkan memiliki pengaruh yang luas dan mendalam. Pada Gambar 13 dapat dilihat proses pengumpulan masalah-masalah yang sangat berkaitan dengan kejadian di sekolah selama melakukan observasi dan wawancara

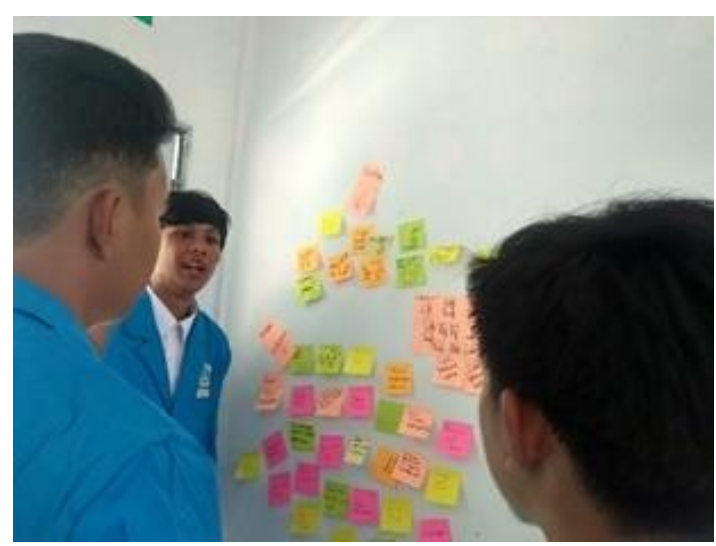

Gambar 14. Proses pengerucutan masalah untuk mendapatkan masalah utama

\section{Purwarupa}

Tahapan curahan gagasan solusi dari masalah utama dilakukan setelah mendapatkan permasalahan utama. Dalam tahapan ini akan disampaikan beberapa konsep solusi bersama anggota peneliti lainnya. Dengan mempergunakan alat tulis yang dituangkan kedalam sketsa.Dapat dilihat pada Gambar 15 menampilkan konsep solusi utama berupa perangkat tirai otomatis yang digambar menggunakan perangkat lunak desain Autodesk Inventor. 


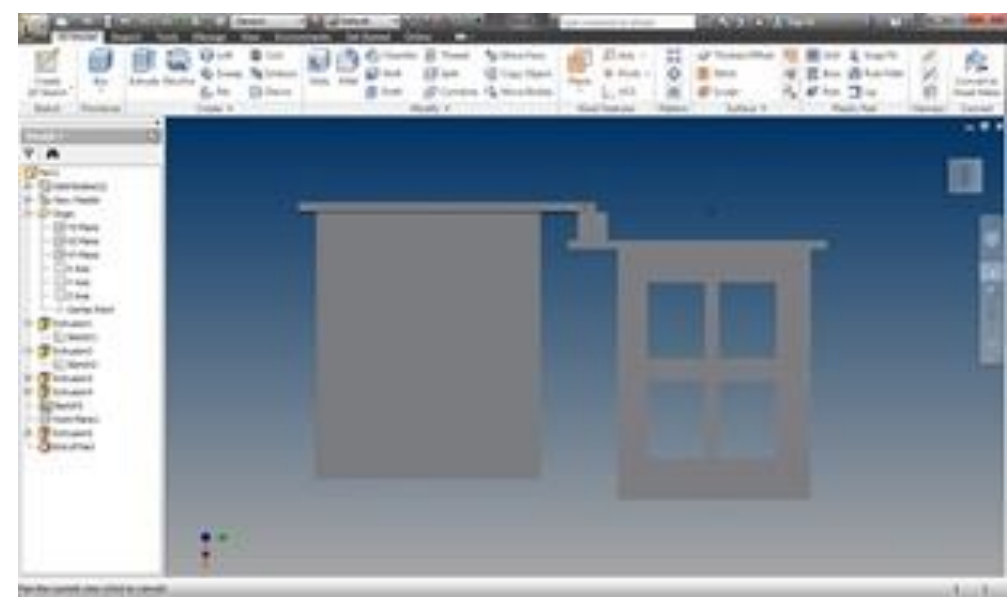

Gambar 15. Purwarupa menggunakan perangkat lunak Autodesk Inventor

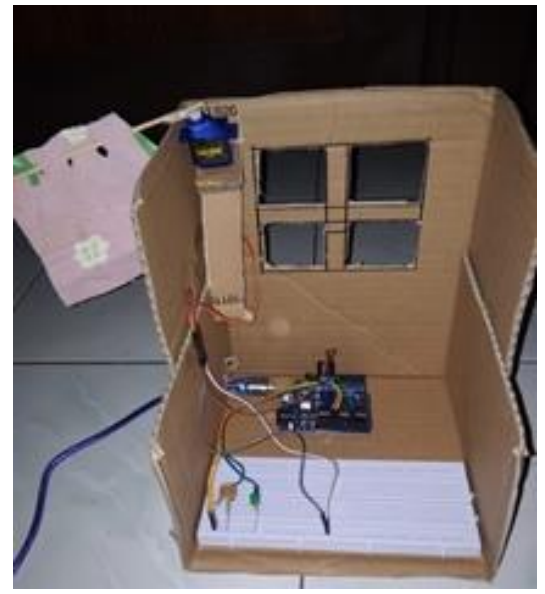

Gambar 16. Purwarupa Sederhana
Tahapan yang sudah mulai memerlukan pembiayaan adalah tahapan pembuatan purwarupa. Oleh sebab itu pada Proses Desain Rekayasa ini, menekankan untuk mampu menghasilkan purwarupa sederhana yang ekonomis dan fleksible, dengan maksud bahwa perubahan rancangan dapat dilakukan dengan mudah dan tidak akan memerlukan pembiayaan yang besar. Purwarupa dalam tahapan ini lebih dikenal dengan istilah low resolution prototype (Nusyirwan, 2017). Dapat dilihat pada Gambar 16 adalah sebuah purwarupa sederhana dari tirai otomatis.

\section{Pengujian Kegunaan}

Pengujian kegunaan adalah proses evaluasi terhadap inovasi yang dirancang dengan berbasis pengguna. Pada tahapan ini pengguna akan berpartisipasi dan berinteraksi secara langsung dengan purwarupa sederhana yang dihasilkan dari proses sebelumnya. Pengguna akan diminta untuk melakukan tugas tertentu atau hanya menjelajahinya secara bebas, sementara perilaku pengguna diamati dan dicatat untuk mengidentifikasi kelemahan desain yang menyebabkan kesalahan atau kesulitan pengguna. Selama pengamatan ini, Setelah kelemahan desain telah diidentifikasi, rekomendasi desain diusulkan untuk meningkatkan kualitas ergonomis produk (Bastien, 2010). Pada Gambar 17 menampilkan uji coba kegunaan untuk mengetahui kerja dan kinerja dari program.

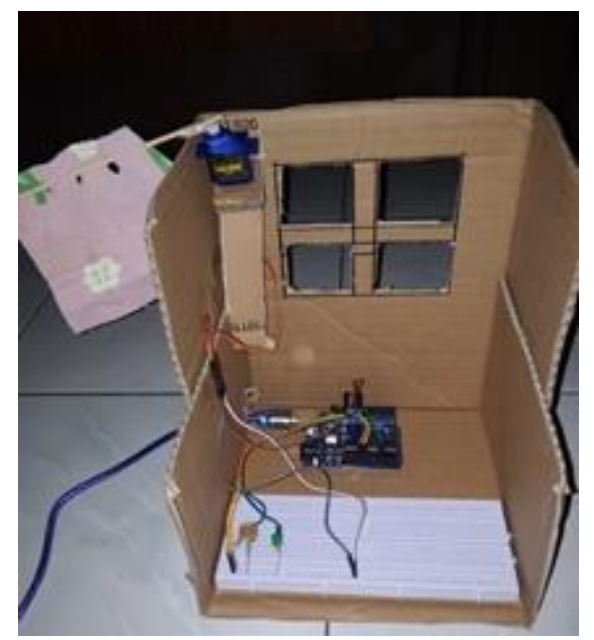

Kondisi awal sebelum berfungsi

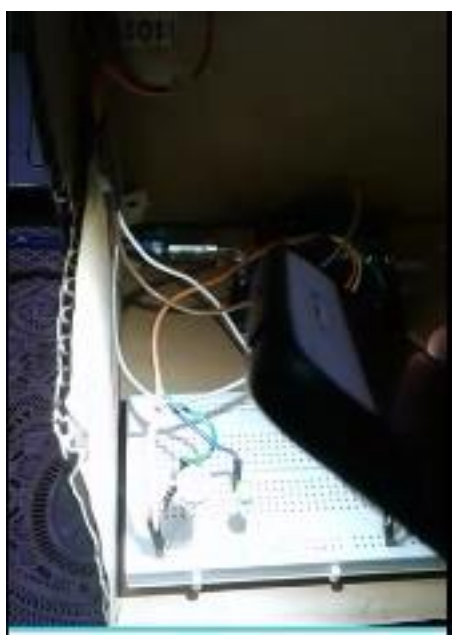

Cahaya yang mengenai sensor LDR

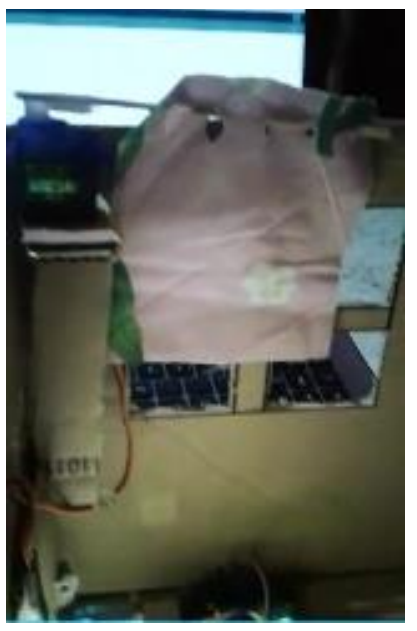

Servo berkerja, Tirai otomatis bekerja

Gambar 17. Pengujian kegunaan purwarupa. 


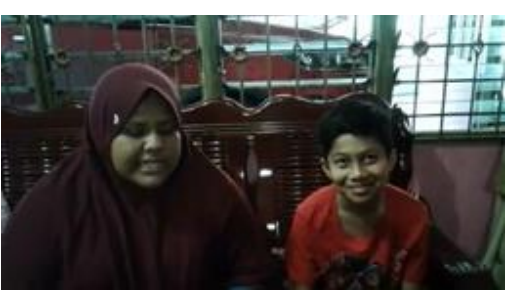

Tahapan awal pengujian bersama calon pengguna tirai otomatis.

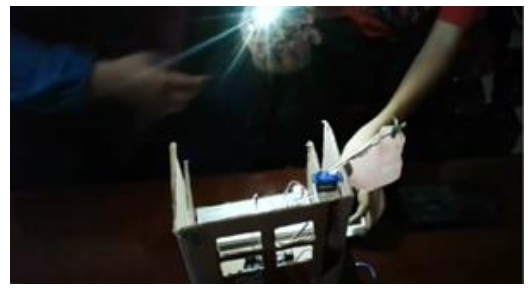

Sensor LDR masih belum mendeteksi cahaya/ terkena sinar. Posisi tirai masih belum bergerak

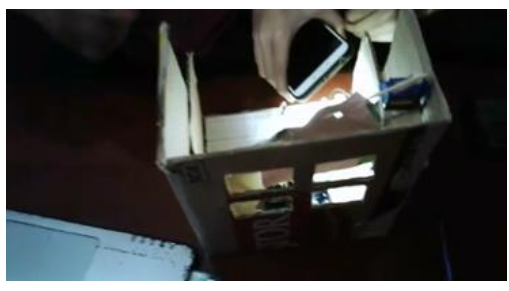

Sensor LDR mendapatkan cahaya dan bergerak menutup jendela di ruangan kelas

Gambar 18. Pengujian kegunaan bersama caon pengguna

Pengalaman pengguna akan memperluas pandangan tentang interaksi produk dengan pengguna dari aspek emosional. Adapun motivasi dari proses pengalaman pengguna adalah untuk mengembangkan pengalaman dan emosi positif. Oleh karena itu, produk harus memenuhi kebutuhan psikologis dan motif pelanggan (von Saucken, Lachner, dan Lindemann, 2014). Pada Gambar 18 menampilkan pengujian kegunaan purwarupa.bersama calon pengguna.

\section{Program pada Arduino}

Dibawah ini adalah program yang ditulis pada Arduino untuk dapat menghasilkan luaran sesuai yang di inginkan pada Tirai Otomatis.
Pada Gambar 19 menjelaskan bahwa sensor LDR (Light Dependent Resistor) adalah sensor cahaya yang bekerja atas perintah cahaya mengikuti arah cahaya sehingga menghasilkan output. Sensor LDR di letakain di pin A0 dan LED di pin 13 arduino uno.

Sedangkan pada Gambar 20 dapat dilihat bahwa program ini menggunakan serial komunikasi 9600 baud, dan ada 2 pin yang digunakan pada arduino untuk input dan output, LED sebagai output dan LDR sebagi input. ketika LDR menerima cahaya maka LDR akan mengeluarkan perintah yaitu menghidupkan LED.

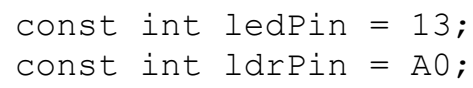

Gambar 19. Inisialisasi dan library komponen.

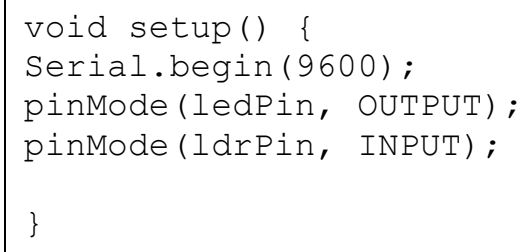

Gambar 20. Void setup untuk mengatur input/ouput komponen. 


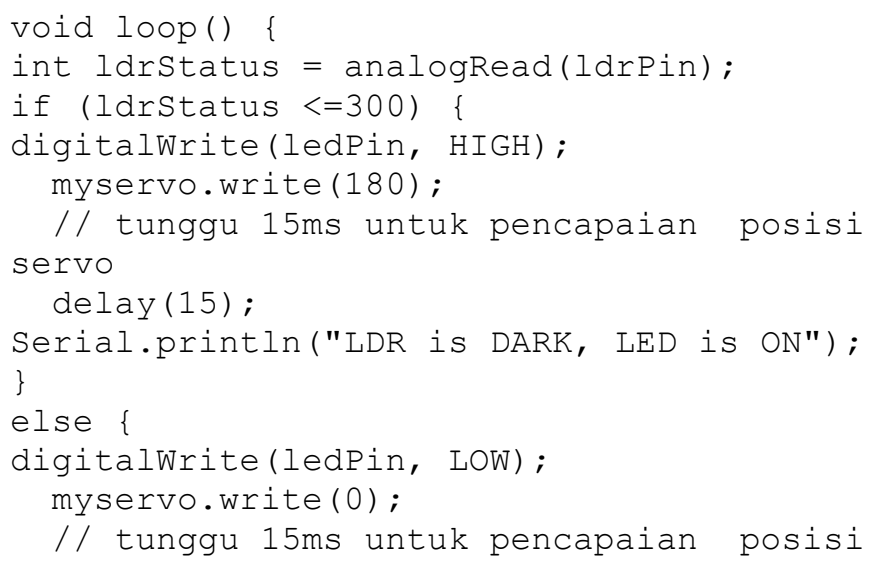

Gambar 21. Void loop sebagai fungsi perulangan perintah program.

Gambar 21 menjelaskan bahwa di dalam void akan diatur perulangan untuk kerja sebuah LDR agar pada saat LDR mendapatkan cahaya maka akan mengeluarkan output dan setelah mengelurkan output akan bekerja kembali. Di dalam void loop di atur pada saat LDR mendapatkan cahaya maka servo akan berputar 180 derajat dan LED akan menyala, ketika LDR tidak mendapatkan cahaya maka servo akan berputar ke 0 derajat kembali dan LED akan mati, begitulah cara kerja dari program ini terus menerus, dan semua yang ada di dalam void loop akan dibaca berulanga kali.

Tabel 2. Hasil Interview dari calon pengguna pertama

\begin{tabular}{|c|c|c|c|c|c|c|}
\hline & 4 & 3 & 2 & 1 & \multirow[b]{2}{*}{ Keterangaan } \\
\hline & & Sangat & Bailk & Cukup & Kurane & \\
\hline 1 & $\begin{array}{l}\text { Purwarupa ini } \\
\text { modah } \\
\text { digunakan? }\end{array}$ & & & & & Teknologi yang sederthana \\
\hline 2 & $\begin{array}{l}\text { Apakah inovasi } \\
\text { ini menarik? }\end{array}$ & & & & & $\begin{array}{l}\text { Berguna untuk } \\
\text { merezantikan yang masih } \\
\text { manual }\end{array}$ \\
\hline 3 & \begin{tabular}{|l} 
Apakah ingvasi \\
ini berguma di \\
linekungan \\
masyarakat?
\end{tabular} & & & & & $\begin{array}{l}\text { marnpu untuk } \\
\text { merapermudah pekerjaan }\end{array}$ \\
\hline 4 & $\begin{array}{l}\text { Apakah fungsi } \\
\text { dari inovasi ini } \\
\text { baik? }\end{array}$ & & & & & sudah cukup baik \\
\hline 5 & $\begin{array}{l}\text { Apakah sistem } \\
\text { dalam inovasi ini } \\
\text { subah optimal ? }\end{array}$ & & & & & sudah optimal \\
\hline
\end{tabular}

\section{DAMPAK DAN MANFAAT KEGIATAN}

Inovator yang berbasiskan teknologi sangat sadar bahwa kesuksesan hasil inovasi tidak hanya dilihat dari manfaat dari produk yang akan dihasilkan namun juga perlu memperhatikan faktor pengalaman pengguna., sehingga pengembangan inovasi teknologi tidak lagi hanya tentang mengimplementasikan fitur dan menguji kegunaannya, tetapi juga tentang mendesain produk yang menyenangkan dan mendukung kebutuhan dan nilai-nilai dasar manusia. Dengan demikian, pengalaman pengguna dalam tahapan Proses Desain Rekayasa harus menjadi perhatian utama pengembangan produk (Johnson, Clegg dan Ravden, 1989).

Tabel 3. Hasil Interview dari calon pengguna kedua

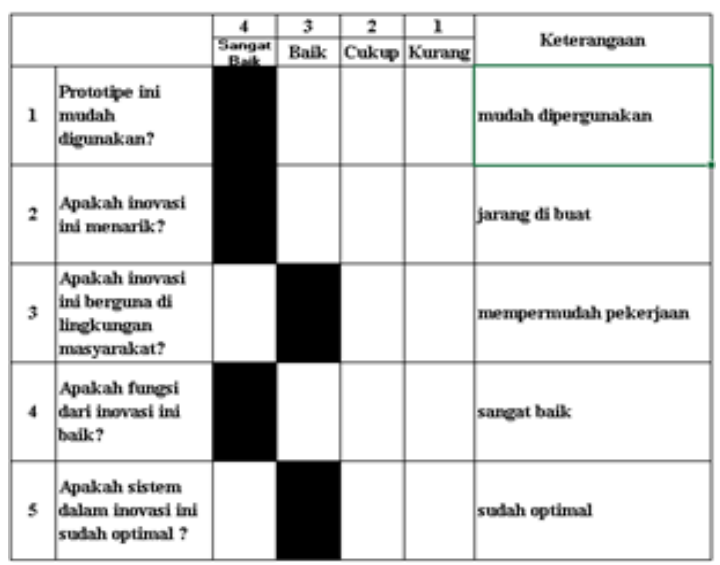


Pada Tabel 2 dan Tabel 3 adalah hasil dari uji coba bersama pengguna untuk mendapatkan informasi terkait fungsi dan manfaat inovasi tirai otomatis untuk sekolah dasar. Dapat dilihat bahwa purwarupa yang dihasilkan sudah dapat memenuhi kretria dasar sebuah inovasi, yaitu mudah dimngerti, sederhana dan dapat diaplikasikan di lingkungan yang menjadi objek penelitian. Dari hasil pengujian tersebut, pengguna berharap bahwa purwarupa untuk dapat lebih memiliki fungsi tambahan lainnya.Tentunya dengan biaya yang terjangkau untuk dapat segera diaplikasikan di sekolah dasar. ,

\section{KESIMPULAN DAN SARAN Kesimpulan}

Dari perancangan purwarupa Tirai Otomatis ini, telah dapat direalisasikan sebuah alat sederhana dengan harga yang terjangkau yang mempergunakan sensor LDR sebagai pengatur buka dan tutupnya tirai, dimana apabila sensor tersebut terkena cahaya maka tirai otomatis akan menutup jendela. Dari hasil pengujian juga dapat dilihat bahwa sistem yang dirancang dapat bekerja dengan baik ketika sensor LDR (Light Dependent Resistor) terkena cahaya. Maka output dari sensor LDR akan dikirimkan ke Arduino untuk kemudian diproses sehingga arduino akan mengontrol servo untuk mengerakkan tirai.

\section{Saran}

Pengujian yang dilakukan terhadap siswa sekolah adalah merupakan sebuah proses awal yang positif untuk menghasilkan sebuah inovasi teknologi yang merupakan solusi bagi masyarakat, oleh sebab itu perlu didukung dengan penelitian yang lebih lanjut dengan menghasilkan purwarupa tingkat menengah yang dapat di ujicoba langsung di beberapa sekolah. Dengan memperhatikan biaya yang akan dikeluarkan maka perlunya kerjasama antara pemerintah daerah dan swasta untuk mendukung program inovasi berbasis pengguna ini.

\section{UCAPAN TERIMAKASIH}

Terima kasih kepada civitas akademika di jurusan teknik elektro Universitas Maritim Raja Ali Haji (UMRAH) dan SDN 003 Binaan Kota Tanjung Pinang.

\section{DAFTAR PUSTAKA}

Ahmad, A., N., dan Dharmawan, A. (2011). Purwarupa Sistem Otomasi Buka Tutup Tirai Berbasis Light Dependent Resistor, Jurnal IJEIS, Vol. 1, No. 2, 21-34

Bastien, J., M., C. (2010). Usability testing: a review of some methodological and technical aspects of the method", International Journal of Medical Informatics, Vol. 79, No. 4, e18-e23.

Budiman, A., Utomo, P., dan Rahayu, S. (2019). Pengembangan Aplikasi Deteksi Dini Serangan Hama Padi Berbasis Android, Jurnal Terapan Abdimas, Vol. 4, No.1, 3339

Discovery \& Strategy [Daring], Tersedia pada : https://www.rareloop.com/services/discove ry-strategy/ [ Diakses : 31 Mei 2019 ].

Ihsanto, E., dan Rifky, M., F. (2015). Rancang Bangun Kendali Gordeng dengan Saklar Lampu Otomatis berbasis Smartphone Android, Jurnal Teknologi Elektro, Vol. 6, No. 1, 28-37

Irbīte, A., dan Strode, A. (2016). Design thinking models in design research and education, Proceedings of the International Scientific Conference, Vol. IV, 488-500

Johnson, G., I., Clegg, C., W., dan Ravden, S., J. (1989). Towards Practical User Experience Evaluation Methods, Jornal of Applied Ergonomics, Vol. 20, No. 4, 255-260

Kastner, S., dan Knight, R., T. (2017). Bringing Kids into the Scientific Review Process. Journal Neuron, Vol. 93, No. 1, 12-14.

Lidiawati, W., Pranoto, L., M., Waslaluddin, dan Hidayat, J. (2017). Otomatisasi Lampu, Tirai, dan Kipas Angin Menggunakan Mikrokontroler untuk Menghemat Energi Listrik, Jurnal Elektronika dan Telekomunikasi, Vol. 13, No. 2, 66-72

Nusyirwan, D. (2017). Engineering Design Process Engineering Student Centered Experience Learning (ESCEL) di Jurusan Teknik Elektro Universitas Maritim Raja Ali Haji (UMRAH). Jurnal Sustainable, Vol. 6. No. 1, 24-35

Sekolah Kita [Daring], Tersedia pada : http://sekolah.data.kemdikbud.go.id/index. php/chome/profil/90AD19BD-31F5-E011B7F8-3B12490BB869 [ Diakses : $31 \mathrm{Mei}$ 2019 ]. 
von Saucken, C., Lachner, F., dan Lindemann, U. (2014). Principles for User Experience What We Can Learn from Bad Examples, International Conference on Kansei Engineering \& Emotion Research

Wagner, C., Kawulich, B., dan Garner, M. (2012). Collecting Data Through
Observation, Doing Social Research: A global context, McGraw Hill

Wulandari. (2017). Prototipe Tirai Otomatis Berbasis Mikrokontroller ATmega 8, Tugas Ahir S1, Universitas Negeri Yogyakarta, Yogyakarta 